\title{
From Irish Philosophy to Irish Theatre: The Blind (Wo)Man Made to See
}

\author{
Einat Adar \\ Charles University Prague, Czech Republic \\ ia_et@yahoo.com
}

Copyright (c) 2017 by Einat Adar. This text may be archived and redistributed both in electronic form and in hard copy, provided that the author and journal are properly cited and no fee is charged for access.

\begin{abstract}
This article traces the motif of the blind man made to see, also known as the Molyneux problem, from the writings of Irish philosophers of the 17th and 18th centuries to 20th-century Irish plays. The narrative of restoring sight to the blind is taken as a paradigmatic example of overcoming a disability, with a cure that normalises the blind persons and allows them to reintegrate into society. The paper argues that this narrative was problematised by Irish philosophers and playwrights from Molyneux and Berkeley to Yeats, Synge, Beckett and Friel.
\end{abstract}

Key Words. Blindness, Irish Philosophy, Social Relations, Samuel Beckett, Brian Friel.

Resumen. En este artículo se investiga el tema de las personas ciegas que recuperan la vista, también conocido como el Problema de Molyneux, acudiendo para ello a los escritos de filósofos irlandeses de los siglos XVII y XVIII hasta llegar a obras de teatro irlandesas del siglo XX. El relato de la recuperación de la visión por parte de personas ciegas se interpreta como ejemplo paradigmático de superación de una discapacidad, a través de una cura que normaliza a los invidentes y les permite reintegrarse en la sociedad. En este trabajo, sin embargo, se apoya la tesis de que este relato se puso en duda por parte de filósofos y dramaturgos irlandeses, desde Molyneux a Berkeley hasta llegar a Yeats, Synge, Beckett y Friel.

Palabras clave. Ceguera, filosofía irlandesa, relaciones sociales, Samuel Beckett, Brian Friel.

Writing about the experience of people with visual impairment, Rod Michalko points out that "Far from being a sheer individual and thus personal experience, blindness is a social one. It is an experience that 'comes to us' - to blind and sighted people alike - always-already framed by and wrapped in the 'one size fits all' conceptual and material cloak of culture" (Michalko 2010). This article examines some aspects of the construction of blindness that "comes to us" from Irish philosophy and the ways in which is worked and reworked in Irish theatre. I will focus on stories of restoring sight to the blind in order to highlight continuities and differences along three main axes - embodied experience, interpersonal interactions, and religious or spiritual discourse.

The narrative of a blind man made to see is taken here as paradigmatic since it explores 
the interface between absence of sight and "normal" vision. Blindness, like any disability, is constructed as a deviation from the standard, a difference that must be explained or overcome: "Blindness time is the time to set its time to rehabilitation, to a person who merely happens to be blind, to being synchronized with the time of being "like-everyone-else"" (Michalko 2010). The restoration of sight should therefore eliminate the difference, removing the deviant and bringing the patient into the fold of normative society. In Irish plays about the curing of blindness, however, the men and women who gain sight find it difficult to re-negotiate their relations with companions and social connections, and often fail in creating a viable position for themselves as sighted people, leading to suffering, banishment, and possible death. This scepticism about the ability of the blind to enter directly into the sighted world can be traced back to the writings of Irish philosophers, especially William Molyneux and George Berkley. ${ }^{1}$ The paper will therefore review the history of the trope of the blind man made to see within Irish philosophy as a background for discussing its re-imagining in four $20^{\text {th }}$ century plays: W.B. Yeats's The Cat and the Moon (1917), J. M. Synge's The Well of the Saints (1904), Samuel Beckett's Rough for Theatre I (1976), and Brian Friel's Molly Sweeney (1994).

\section{The Blind Man in Irish Philosophy}

Defining what Irish philosophy is, who should be included under this title, and whether the term is even a meaningful way to describe a certain collection of philosophical texts is a vexed question that will not be broached here. Instead, the discussion will follow David Berman in focusing on the distinct school of thought that developed in Ireland between the 1690s and 1750s:

It was born with John Toland, grew with Peter Browne, William King, George Berkeley and Francis Hutcheson, and died with Robert Clayton and Edmund Burke. This tradition was largely autochthonous or indigenous, and it engaged most of the outstanding Irishmen of the time, as well as a host of lesser figures. (2005: 79)

Among the philosophers of this Irish school, two stand out for their contribution to the discussion on blindness: William Molyneux and George Berkeley.

In recent years there has been a growing interest in the role of vision in early modern philosophy, from Descartes onwards. For the Enlightenment thinkers, as the name might indicate, vision was the main instrument for learning about the world, and a metaphor for cognition in general. This centrality of vision, commonly termed "ocularcentrism", was fundamental for modern philosophy and as Martin Jay shows, was severely critiqued by the French poststructuralists of the $20^{\text {th }}$-century. In Blindness and Enlightenment Kate E. Tunstall argues that alongside the centrality of vision in the $18^{\text {th }}$-century, there was an important literary and philosophical tradition concerned with blindness and the figure of the blind man (2011: 14). Her argument concurs with Michel Foucault's observation in The Birth of the Clinic, that there were "two great mythical experiences on which the philosophy of the eighteenth century had wished to base its beginning: the foreign spectator in an unknown country, and the man born blind restored to light" (2003: 65). If vision was conceived as the most direct and accurate mode of cognition, then the restoration of vision served as a metaphor for the discovery of truth, and the blind man who regains sight was compared to a child learning a new lesson, or a scientist discovering a law of nature. Thus, the primacy of vision as a metaphor for a privileged access to truth induced a closer attention to blindness and its incorporation into the epistemological field.

For Foucault, who writes mostly about French history, the metaphor of the blind man regaining sight is primarily concerned with knowledge, describing the way in which the truth 
about the world is revealed to a person who has no prior experience of it, and therefore no prejudice or pre-conceived ideas that would interfere with immediate experience. This very metaphor, however, was itself developed in a particular historical context and in carries resonances and associations that make this embryonic narrative very different from the clean slate it advocates as a guarantee of truth. The history of the trope is especially important within the Irish context, since, as Berman argues, "The similitude of the blind man is more than a mere illustration. It is the root metaphor, as it were, of Irish philosophy. And it is hardly an accident that the Molyneux problem, with which it is clearly associated, was very much an Irish problem" (2005: 87). The close association of restored sight with religious revelation and miracles constitutes an important intertext for early modern thinkers in Ireland. The ability of a person who was blind from birth to understand visual input after an operation to restore sight was first questioned by William Molyneux, who wrote an important treatise about optics and whose wife was blind. Molyneux was a proponent of John Locke, to whom he sent this inquiry in 1688:

a Jocose Problem ... Suppose a Man born blind, and now adult, and taught by his Touch to Distinguish between a Cube and a Sphere (Suppose) of Ivory, nighly of the same Bignes, so as to tel, when he felt One and tother, Which is the Cube and which the Sphære. Suppose then, the Cube and Sphære placed on a Table, and the Blind man to be made to see. Quære whether by his sight, before he touchd them, he could now Distinguish and tel which is the Globe which the Cube. (De Beer 1979: 651. Original spelling retained)

The Molyneux problem has been extensively discussed in philosophy ever since its introduction and is still being referred to in cognitive and psychological studies, including Oliver Sacks' An Anthropologist on Mars, which was a major source for Brian Friel's play, Molly Sweeney. The problem questions a basic assumption of Enlightenment epistemology - the ability of a person without preconceived knowledge and prior experience to directly understand sense impressions. The blind man trying to compare the light and colours he is seeing for the first time with the objects he has long known by touch can be seen as an epistemological metaphor for the way any person understands radically new information about the world. Molyneux is using a practical setting to concretise the problem, turning it from an abstract metaphor into an embodied experience of a specific individual with a specific knowledge, trying to achieve a specific goal.

One of the most famous answers to the Molyneux problem comes from George Berkeley, who contended that the blind man will not even understand the question. In his first major work, A New Theory of Vision, he argues that knowledge of distance and form is not achieved through direct perception, but derives from a combination of visual cues and corresponding tactile sensations - an ability that must be acquired by experience (Berkeley 2000a: 47). A man who recently gained sight will be literally unable to see a cube and a globe in front of him, perceiving only a coloured plane without depth or distance that he must learn to interpret in order to discern separate objects and relate the different colours to distance, size, and form. As Branka Arsić summarises, "The visible world never offers itself to the gaze as a world nicely formed into geometrical bodies" (2003: 50).

Despite the common-sense attitude adopted by both Molyneux and Berkeley, the problem of what blind people can understand about sighted experience was mainly interpreted within a theological context in Ireland. Berman provides two prominent examples from this period - Peter Browne (1671-1735) and Edward Synge (c. 1690-1762), who both compared the belief in religious matters to a blind person who is asked to believe in the existence of light and colour that she cannot see herself. (2005: 86). For these writers, the knowledge to be discovered 
by the senses is primarily the truth of religion. What to us may seem like a scientific or psychological problem, for the Irish philosophers "turns precisely on the question of representation; and at the core of the dispute lies the issue of our knowledge of God", according to Terry Eagleton (1995: 50). The challenge to religion posed by the Molyneux problem may be gauged when compared with a blind man imagined much earlier by the $12^{\text {th }}$ century philosopher Abu Bakr Ibn Tufayl, whose writings may have inspired Molyneux as well: ${ }^{2}$

imagine a child, growing up in a certain city, born blind, but otherwise intelligent and well endowed, with a sound memory and an apt mind. Through his remaining channels of perception he will get to know the people as well as all sorts of animals and objects, and the streets and alleys, houses and markets - eventually well enough to walk through the city without a guide, recognizing at once everyone he meets ... Suppose after he had come this far, his eyesight were restored and he could see. He would [find] nothing in contradiction to what he had believed, nor would anything look wrong to him ... Still there would be two great changes, the second dependent on the first: first the daybreak on a new visual world, and second, his great joy. (Ibn Tufayl 2009: 97)

The Molyneux problem challenges Ibn Tufayl's confident assumption that a blind man will be immediately able to identify his new vision with what he learned from his seeing peers, the use of his other senses and the application of reason. This implies, in its turn, a doubt as to whether the exercise of the limited faculties of our human mind can attain knowledge of the divine.

When Berkeley answers the Molyneux problem in the negative, he reinforces its sceptic attitudes towards the possibility of "pure" knowledge that is untainted by prejudice or experience. Berkeley is careful to distinguish between the theological and epistemological aspects of the Molyneux problem, contending that "we have some notion, though infinitely inadequate, of those divine attributes, yet still more than a man blind from his birth can have of light and colours" (Berkeley 2000b: 233. Emphasis mine), and yet the doubt cast on human cognition lingers and the nature of the notion that we have of God remains unspecified (Hill 2010: 3-15).

In addition to the cognitive, experiential and religious aspects of the Molyneux problem, it should be noted that the situation described in it involves an interpersonal interaction. It is most clearly detailed in Ibn Tufayl's description of the townspeople teaching the blind child about his surroundings, but a similar educational act is also implied in Molyneux' more succinct formulation. The man is "taught" to distinguish the cube from the sphere, and is later "made" to see. The passive verbs obscure the identity of the persons who performed these acts, but they must nevertheless exist, and the blind man's interaction with them is necessary to the experiment. Such interaction becomes crucial in $20^{\text {th }}$ century Irish theatre.

\section{Saintly Cures: Restoration of Sight in early $20^{\text {th }}$-century drama}

In early $20^{\text {th }}$-century two plays stand out for featuring the restoration of sight: W.B. Yeats' The Cat and the Moon and J.M. Synge's The Well of the Saints. Both plays share with Irish philosophy an interest in religion and mysticism and highlight the importance of interpersonal exchange in the restoration of sight. In Yeats's The Cat and the Moon a blind beggar is persuaded by his lame companion to find a saint who can cure both of their afflictions. The blind beggar is concerned with material things and even questions the utility of gaining his eyesight, since this would put him at a disadvantage in begging. The lame beggar is more spiritual, speculating that "maybe we'll see the blessed saint this day... and maybe that will be a grander thing than having my two legs" (Yeats 2001: 308). The difference between the two 
beggars is brought into relief when the saint asks them "Will you be cured or will you be blessed?" (309), forcing them to choose between physical and spiritual well-being. Each beggar answers according to his inclination - the materialistic blind chooses a cure for his blindness, while the spiritual cripple prefers to be blessed by the saint. The process of the cure

is simple, consisting of nothing more than an evocation of the holy trinity, and has immediate effect - the blind man responds with "I see it all now" (310). He then proceeds to describe what he sees which includes the sky, a tree and the well, as well as other details of scenery. Unlike the blind imagined by Molyneux, he has no difficulty in identifying what he has hitherto only felt by touch or heard about from others, such as the sky.

This restoration of sight has a negative side for both beggars, as the formerly blind man notices that his companion has stolen a sheepskin from him. The discovery of the theft breaks the connection between the two men, and the formerly-blind one leaves after beating up the thief. Thus, the eyes of the blind are opened not only to the beauty of nature, but also to the ugliness in human relations. Finally, it is important to note that the blind man remains partially blind, since he cannot see the saint who cured him (310). It is implied that his inability to see the saint stems from his material inclination and his choice to reject the blessing of the saint, a partial blindness that is noteworthy as a precedent for the other plays to be discussed here.

In contrast to Yeats's symbolic play, Synge's The Well of Saints focuses on social relations between the blind characters and the other people in the village. The play tells the story of Mary and Martin Doul, a blind couple who believed they were extremely beautiful until a passing saint gives them vision. Like Ibn Tufayl's intelligent blind man, they thought they knew everything about their environment through the descriptions of their fellow-villagers, but instead of teaching them the villagers were pulling a cruel joke at their expense. The couple's attempt to integrate into the life of the village as seeing people is short-lived and ends in disappointment and a return to blindness. When the saint arrives to restore their sight a second time, this time permanently, they refuse and are cast away from the village, possibly going to their death.

The restoration of sight is performed off-stage, but like the miraculous cure of the blind beggar, it is religious in nature and immediately effective. The water that cures blindness must be delivered by a "a fine holy man ... a saint of the Almighty God" (Synge 2001: 137) and the saint affirms that God "[will] have pity on you, and put sight into your eyes" (141) Moreover, the failure of a cure is due to moral and social reasons, not physical or cognitive ones - after their sight is restored, the Douls find it difficult to adjust to the idea of working for a living. Ironically, the saint who gives them sight, and who portrays himself as forgiving and generous, is the one instigating the villagers to chase the blind couple away at the end of the play. The blind couple had their eyes opened to the deceitfulness and narrow-mindedness of their community, and this revelation creates an irreparable rift between them and their neighbours.

The disturbed relations between the blind couple and the villagers contains an inherent critique of the assumption that the sighted experience of reality is superior. The seeing people in the play take it for granted that Martin and Mary Doul lead a miserable life because they are unable to see, but in fact the couple enjoys its own world which is as rich and satisfactory for them as the world of the seeing. At the beginning of the play the Douls are also shown to be confident in their knowledge of themselves and their environment. After experiencing both sighted and blind life, the couple prefers to stay blind. Mary Doul tells the saint: "Let us be as we are, holy father, and then we'll be known again in a short while as the people is happy and blind, and be having an easy time, with no trouble to live, and we getting halfpence on the road" (167). Faced with the determination of the villagers and the saint to give Mary sight again, Martin Doul lashes out:

If you're a fine Saint itself, it's more sense is in a blind man, and more power maybe 
than you're thinking at all ... I'm thinking it's a good right ourselves have to be sitting

blind, hearing a soft wind turning round the little leaves of the spring and feeling the sun, and we not tormenting our souls with the sight of the gray days, and the holy men, and the dirty feet is trampling the world. (170)

In this final speech, Martin Doul attempts to reclaim his own dignity and separate identity, even while he is being driven away to a possible death. The Douls' affirmation of their separate identity makes the case for a view of knowledge as composed of heterogeneous discourses which are equally valid, against the strict hierarchies of the saint who in this context represents not only the church, but also the claim to rationality of Enlightenment epistemology. As Mary Burke writes, the play "ostensibly pits settled culture and broadly allied and implicitly admirable 'unsettled' subcultures in opposition ... Synge ... reveals that the perceived moral chasm between the minority and majority communities is largely constructed" (2009: 45).

The creation of an individual, isolated world may be criticised as a turning away from reality, and according to Ronan McDonald, Synge himself had doubts about the value of such private worlds: "The scientist in Synge refuses the idea that the imagination can wholly redeem and transform reality. It can ... transform people's perceptions of themselves... but perceptions of the external world are far less liberating" (2002: 65). This very criticism, however, rather begs the question by assuming the existence of an objective external reality that can best be understood through science. Regardless of Synge's personal judgement of the fantasy world preferred by the Douls, the play makes a powerful case for the existence of incommensurable types of experience.

As in The Cat and the Moon, the blind couple open their eyes to discover the lies told them by the very people who persuaded them to cure their blindness, in marked contrast to the benevolence of the teachers and physicians implied by the Molyneux problem. Synge's play complicates the question of how can we interpret sensations of a completely new type by introducing a diversity of experiences that are equally valid. At the same time both Yeats and Synge share with earlier Irish philosopher an interest in the experience of blind people as a way to understand the encounter with any kind of new experience, as well as a practical approach and a realistic assessment of the difficulties involved in adjusting to new forms of knowledge.

\section{A Blind Woman Made to See: Brian Friel's Molly Sweeney}

While Yeats and Synge pass in silence over the cognitive troubles encountered by blind people who suddenly gain sight, later Irish playwrights seem more attuned to it. A case in point is Brian Friel's Molly Sweeney which dramatises the Molyneux problem in a modern setting. Both Molyneux and Berkeley are mentioned by name with the addition that each was an "Irishman by the way" (Friel 1996: 368). Friel's play tells the story of a blind woman who despite her disability led a satisfying life. She was working as a massage therapist, won swimming competitions, and was popular among her friends. In her husband's eyes, though, this was not enough. Together with Dr. Rice, who dreams of restoring his shattered professional reputation, he persuades Molly to undergo an operation that will give her partial sight. The operation is successful, but the results are disastrous. After her initial exhilaration, Molly is unable to cope with the cognitive stress of the new sense and suffers from a condition that renders her practically blind again, has a nervous breakdown and relates her story from a bed in a psychiatric hospital.

Molly's story closely follows a case history described by Oliver Sacks in An Anthropologist on Mars, where both Molyneux and Berkeley are mentioned as the first thinkers to raise the question and provide an answer that has been proven by later scientific discoveries 
to be correct (1995: 110). The difficulty of making sense from visual perception is described in detail in the medical case study, and repeated by Molly when the bandages are taken off after the operation:

'Now, Molly. In your own time. Tell me what you see.' Nothing. Nothing at all. Then out of the void a blur; a haze; a body of mist; a confusion of light, colour, movement. It had no meaning.

'Well?' he said. 'Anything? Anything at all?'

... 'Well? Anything?' Something moving; large; white. The nurse? And lines, black lines, vertical lines. The bed? The door? (350)

As in the plays previously discussed, Friel pays a lot of attention to the social setting in which the eye operation takes place, and the relations between the characters. Molly's husband is a chaser of lost causes, whose misguided attempts to improve the world repeatedly end in failure and cause harm to the creatures he tries to help. When he makes his wife's blindness his new project, the audience can already sense that Molly will only suffer as a result. The choice of writing the play about a female patient, rather than a male as in Sacks' medical case, serves to highlight the power relations between Molly and the men who coax her into an operation she did not seek herself.

The story of the blind woman made to see continues the Irish tradition in its evocation of a mystical dimension, even though both disability and cure are presented in medical terms. This dimension is evident in the exaggerated expectations of Molly's husband and her own feeling that her medical examination involved "questions about good and evil and about the source of knowledge and about big mystical issues!" (368). In George O'Brien's words, they are concerned with "vision, healing, belief and beginning anew" (2006: 94). All three characters in the play speak about a "fantasy" that propels their actions. For Molly, the fantasy is to discover a new and mysterious world:

If there was a phantom desire, a fantasy in my head, it was this. That perhaps by some means I might be afforded a brief excursion to this land of vision ... And during my stay to devour it again and again with greedy, ravenous eyes. To gorge on all those luminous sights and wonderful spectacles ... And then, oh yes, then to return home to my own world with all that rare understanding within me for ever. (Friel 1996: 349-50)

Molly's description of a successful operation is akin to a mystical experience - a literally eye-opening moment of revelation that will give her access to a "rare understanding" that is beyond her world (350). The play can thus be seen to follow the tragic plot of a hubristic attempt by Molly, her husband and her doctor, to overcome the limits of the knowable. The harsh realities of coping with the consequences of the operation will wake all three from their fantasy, and punish Molly cruelly. As Christopher Murray comments, "Even a little learning is a dangerous thing, how dangerous we usually prefer not to consider" (1998: 93). The knowledge Molly gains with the restoration of her sight is so difficult to reconcile with her previous experience of the world that she rejects it completely, renouncing her fantasy of salvation.

Like the Douls in The Well of the Saints, Molly enjoys her blind world and rejects her characterisation as miserable or crippled, explaining that "I know only my own world. I didn't think of it as a deprived world. Disadvantaged in some ways; of course it was. But at that stage I never thought of it as deprived" (Friel 1996: 336). Unlike Martin Doul, though, Molly comes to accept the point of view of the male figures who dominate her life and avoids confrontation with the hierarchical ordering of knowledge imposed on her. She continuously expresses gratefulness to her husband and her doctor even though she is paying the highest price for the forbidden knowledge they tried to give her. After the failure of her sight and her mental deterioration, she relinquishes the attempt to validate her own experience. For her, "Real - 
imagined - fact - fiction - fantasy - reality - there it seems to be ... And why should I question any of it any more?" (370). These words, which end the play, may lead the spectators to reconsider the assumption that sight is superior to blindness, but the suggestion is undercut by the fact that they are spoken from a mental hospital bed. Molly Sweeney may have gained access to an alternative form of truth after losing her sight for the second time, but this new knowledge remains liminal and without authority. Furthermore, she is unable to express it without resorting to her husband's terms "what I take to be imagined may very well be real what's Frank's term? - external reality" (370. Emphasis mine.)

The story of Molly Sweeney challenges many of the assumptions implicit in the Molyneux problem - the benevolence of the father who taught Molly to overcome her disability, and even more so the good intentions of the eye specialist who gives her partial sight even though he senses that it may ruin her. It also strongly qualifies the progressive narrative of a blind person who gains sight and will henceforth become the same as sighted people. The story does not end when Molly manages to discern different objects, in fact it just begins because right from the beginning of the play Molly is hospitalised with a complex condition caused by her failure to adjust to vision. The optimistic and progressive Enlightenment narrative becomes a tragedy in Molly Sweeney, where the need of empowered male figures to improve and experiment result in marginalising and silencing a female subject.

\section{The Blind Man and the Cripple yet again: Samuel Beckett's Rough for Theatre I}

The Molyneux problem, which is directly referred to by Friel, informs one of the plays of another famous Irish playwright - Samuel Beckett - in a more covert form. Even though the play does not refer to the problem directly, or indeed features a medical or miraculous restoration of sight, it can be seen to dramatise the story of a blind man made to see in an altered, but still recognisable form.

The play features two unnamed characters, a blind man and a cripple, who strongly evoke Yeats's The Cat and the Moon. It is set in a post-apocalyptic urban space, where A, a blind beggar, is playing his fiddle on a street corner. B, a cripple in a wheelchair arrives to see where the music is coming from. B's initial impulse to withdraw is checked when it occurs to him that he main join forces with the blind beggar "and live together" (Beckett 1990: 227). B wants to join forces with A, similar to the beggars in Yeats's play but the crucial difference is that $\mathrm{A}$ and $\mathrm{B}$ have not yet formed such a bond. In order to achieve his goal, B offers a union couched in a discourse of courtship. He muses they could "live together, till death ensue" (227), asks A whether he thinks that "we could make a match", and later confirms that "If you ask me we were made for each other" (229). A remains unmoved and only the mention of tinned food elicits a response from him, though even this is not enough to convince him. Dramatic tension is thus generated by B's attempt to woo A out of his apathy and form a couple with him.

Unlike the blind beggar in Yeats's play, however, A is not exclusively interested in material things and is asking B for more information about the world around him. A's first question is "How are the trees doing?" (228). Trees are a motif that may suggest nature, regeneration, or even a source of food. But they are also a popular example of a remote object in treatises on optics. Berkeley writes about "the magnitude of anything, for instance a tree or a house" (Berkeley 2000a: 23). A confirms that unlike Molly Sweeney before her operation, he cannot perceive light and colour by remarking that "It seems to me sometimes I spend the night here, playing and listening." (Beckett 1990: 228). Later in the play he will ask about the colour of B's wen and "Is there no green anywhere?" (232). A insists on questioning B about what he sees but B is reluctant to answer, and to A's question "But you look about you?", B responds violently "No!" (230). Finally, A says that he was "always" blind (228), like the man in the Molyneux problem. A's preoccupation with external appearances also calls to mind the Douls 
from Synge's The Well of the Saints but more importantly, he is a blind man who wishes to see. His desire for knowledge is directed at practical things, but also at general information about the world.

In Beckett's bleak outlook there is no moment in which truth is revealed, be it the scientific truth of the medical profession, a mystical truth of God, or a personal truth about one's partner. And yet, B's offer seems to promise an increase A's knowledge of the world:

B: ... Of course if you wish me to look about me I shall. And if you care to push me about I shall try to describe the scene, as we go along.

A: You mean you would guide me? I wouldn't get lost any more?

B: Exactly. I would say, Easy, Billy, we're heading for a great muckheap, turn back and wheel left when I give you the word ... I see a round tin over there in the gutter, perhaps it's soup, or baked beans. (230)

The mention of baked beans manages to elicit a positive reaction from A for the first time in the play, but there is a difference between B's offer to "describe the scene" and A's utilitarian interpretation of the request that he would "guide" him, which B picks up immediately by describing how he could help A avoid obstacles and find food. He thus transitions from aesthetic description to the practicalities of finding one's way in the world. The attempt by A and B to form a couple, however, is expressed in the play not only as a practical union, but also as a religious revelation:

A: Baked beans! [He gets up, puts down fiddle and bowl on the stool and gropes towards B.] Where are you?

B: Here, dear fellow. [A lays hold of the chair and starts pushing it blindly.] Stop!

A: [Pushing the chair] It's a gift! A gift! (230)

The ejaculation "It's a gift!" conveys A's enthusiasm in terms of a miraculous cure, a term that was also used by Frank Sweeney when he imagines the sensationalist headline in the newspaper - "Miracle of Molly Sweeney. Gift of sight restored to middle-aged woman" (Friel 1996: 338). The combination of A's ambulatory powers with B's vision creates a compound creature that gives some form of sight to the blind A. It is probably the closest a Beckett character can get to improving its powers of perception. Thus, although the union of $\mathrm{A}$ and $\mathrm{B}$ is not an accurate repetition of the Molyneux problem, it still situates itself within the parameters of this problem.

Inevitably, a Beckett play allows for no miracles and the direct result of A's enthusiasm is that B changes his attitude, hitting him with the pole to stop him from madly pushing the wheelchair around (Beckett 1990: 230). A is yet another figure in Irish theatre who is promised sight, but is unable to make use of it and loses it again, like the blind man in The Cat and the Moon who gains material sight but cannot see the saint, the Douls in The Well of the Saints who choose to stay blind and Molly Sweeney who resigns herself to a state between vision and imagination. The pursuit of knowledge and practical utility implied in the trope of the blind man made to see, together with the aspiration to transcend human knowledge, repeatedly fail.

Beckett's play can be seen as the most extreme form of this failure, with the attempt ending almost as soon as it begins. At the moment of ecstasy when A grabs the chair and endows B with motion, B offers no visual description, only a blow with the pole so that the man born blind remains as blind as ever. In return, A doesn't take B anywhere. In both The Cat and the Moon and The Well of the Saints, the blind who are granted sight can immediately use their new sense, just as well as seeing people. Molly Sweeney is able to gain some vision after her operation and initially feels elated and delighted. The blind A never enjoys the visual description of B who rejects him immediately. 
The trope of the blind man made to see which was central to Irish philosophy is critiqued in Irish theatre from different angles. Proposed as a way to cast doubt on our ability to understand unfamiliar sense impressions, it involves an interplay of personal identity, social relations and the limits of knowledge. The crux of Berkeley's answer to the Molyneux problem is the need for a process of learning before a blind man can understand what he sees. For Yeats and Synge the knowledge gained through the new sense breaks up previous connections and reveals the negative side of the social fabric. In Friel, the fate of the blind woman is being overtaken by men who leave her to pay the price for their hubris on her own. Finally, the unwillingness of Beckett's beggars to cooperate strikes a sceptical note regarding the human ability to transition from seeing to understanding, not because they are unable to do so, but because they do not try.

\section{Notes}

${ }^{1}$ On the relation between Irish theatre and Irish philosophical "idealism" see Smith (2011) and Pilný (2006: 1123) on the tension between realism and idealism in Yeats's theatrical project.

2 Ibn Tufayl's work has been widely read in the $17^{\text {th }}$ century and was first translated into English in 1674. John Locke was almost certainly acquainted with the work in Latin translation, see Russell (1994).

\section{Works Cited}

Arsić, Branka. 2003. The Passive Eye: Gaze and Subjectivity in Berkeley (via Beckett). Stanford: Stanford University Press.

Beckett, Samuel. 1990. "Rough for Theatre I". The Complete Dramatic Works. London \& Boston: Faber and Faber. 225-234.

De Beer, E. S. (ed.). 1979. The Correspondence of John Locke, vol. 4. Oxford: Clarendon Press. Berkeley, George. 2000a. "An Essay towards a New theory of Vision". Philosophical Works including the Works on Vision. Ed. Michael R. Ayers. London: Everyman. 3-59. 2000b. "The Theory of Vision Vindicated and Explained". Philosophical Works including the Works on Vision. Ed. Michael R. Ayers. London: Everyman. 229-250.

Berman, David. 2005. Berkeley and Irish Philosophy. London \& New York: Continuum.

Burke, Mary. 2009. "The Well of the Saints and The Tinker's Wedding". The Cambridge Companion to J. M. Synge. Ed. P. J. Mathews. Cambridge: Cambridge University Press. 41-51.

Eagleton, Terry. 1995. Heathcliff and the Great Hunger: Studies in Irish Culture. London \& New York: Verso.

Foucault, Michel. 2003. The Birth of the Clinic: An Archaeology of Medical Perception trans. A. M. Sheridan. London: Routledge.

Friel, Brian. 1996. "Molly Sweeney". Brian Friel Plays: 2. London \& Boston: Faber and Faber. 324-370.

Hill, James. 2010. “The Synthesis of Empiricism and Innatism in Berkeley's Doctrine of Notions", Berkeley Studies, 21. 3-15.

Ibn Tufayl, Abu Bakr. 2009. Ibn Tufayl's Hayy Ibn Yaqzān: A Philosophical Tale, trans. Lenn Evan Goodman. Chicago and London: University of Chicago Press.

Knowlson, James and John Pilling. 1979. Frescoes of the Skull: The Later Prose and Drama of Samuel Beckett. London: John Calder.

Michalko, Rod. 2010. "What's Cool about Blindness?” Disability Studies Quarterly, 30. 3-4. http://dsq-sds.org/article/view/1296/1332 [retrieved 09/11/2016]

McDonald, Ronan. 2002. Tragedy and Irish Literature: Synge, O'Casey, Beckett. London: Palgrave. 
Murray, Christopher. 1998. "Brian Friel's Molly Sweeney and its Sources: A Postmodern Case History”. Études Irlandaises, 23. 2. 81-98.

O'Brien, George. 2006. "The Late Plays". The Cambridge Companion to Brian Friel. Cambridge \& New York: Cambridge University Press. 91-103.

Pilný, Ondrej. 2006. Irony and Identity in Modern Irish Drama. Prague: Literaria Pragensia.

Russell, G.A. 1994. "The impact of the Philosophus autodidactus: Pocockes, John Locke, and the Society of Friends". The 'Arabick' interest of the natural philosophers in seventeenth-century England. Leiden, New York \& Köln: Brill. 224-265.

Sacks, Oliver. 1995. "To See and Not to See". An Anthropologist on Mars: Seven Paradoxical Tales. New York: Alfred A. Knopf. 108-152.

Smith, Eoghan. 2011. "Yeats, Beckett, Banville: Philosophical Idealism and Political Ideology in Modern Irish Writing". ABEI Journal, 13. 71-82.

Synge, John Millington. 2001. "The Well of the Saints". The Complete Plays. London \& New York: Bloomsbury. 132-171.

Tunstall, Kate E. 2011. Blindness and Enlightenment: An Essay with a New Translation of Diderot's 'Letter on the Blind' (1749) and a Translation of La Mothe le Vayer's 'Of a Man-Born-Blind' (1653). New York \& London: Continuum. 224-265.

Yeats, W.B. 2001. "The Cat and the Moon". The Collected Works of W.B. Yeats Vol. II: The Plays. Eds. David R. Clark and Rosalind E. Clark. New York: Scribner. 307-312.

Received: 10 November 2016 Revised version accepted: 5 February 2017

Einat Adar is a PhD student at the Centre for Irish Studies at Charles University Prague, Czech Republic, working on Samuel Beckett's engagement with the philosophy of George Berkeley. Her work has been published in Tradition and Modernity: New Essays in Irish Studies (2014) - a collection of essays in Irish Studies which she also co-edited - and in Partial Answers (2016). 